\title{
Existing Evaluation and Efforts to Improve the Distribution Network of Banyuwangi District PDAM (Banyuwangi City Study Area)
}

\author{
Danang Budi Setyawan ${ }^{1}$, and Nieke Karnaningroem ${ }^{1}$
}

\begin{abstract}
The drinking water sector is the aspect of development that has a pivotal function to support the welfare of society. This is due to health, lifestyle, residential environment conditions and comfort in daily life. The service of the piped water supply system (SPAM-JP) for the service of the capital city of Banyuwangi Regency covers 5 Subdistricts, with 44\% clean water service coverage, installed production capacity of 405 liters/second and operating 330 liters/second, to service 34,319 Connection Units with customers domestic (Household) as many as 32,271 units and non-domestic as many as 2,046 units of connection. In addition, the level of continuity has not yet been achieved, this can be seen in some service areas during peak hours not flowing, besides the level of water loss is 25\%. In anticipating all problems in the service, research is conducted by analyzing the technical aspects, financial aspects, and institutional aspects. In analyzing each aspect, it was used the appropriate method and updated data. The technical aspects was done by calculating water balance uses easy calk, network analysis using epanet 2.0 and determining improvement efforts. In the institutional aspects was done by the assessment of BPSPAM, while the financial aspects by analyzing the investment costs of network improvements required and alternative funding. The evaluation of existing conditions is that the production and distribution units are not optimal, in the water balance the water loss is $25 \%$, from the HR assessment there is no activity to improve the existing $H R$ and efforts to improve the distribution network include general improvements in the form of pipe replacement and DMA formation in all service areas and managements, namely by increasing $H R$ and developing computer-based information systems.
\end{abstract}

Keywords-Drinking Water, Continuity, Water Loss.

\section{INTRODUCTION}

The drinking water sector is an aspect of development that has an important function in supporting the level of community welfare. This is due to health, lifestyle, residential environment conditions and comfort in daily life. So that along with the increase in population, it also increases the demand for water.

Drinking water supply system by PDAM with five subdistricts. fulfillment of PDAM drinking water services using five springs and five drill well[1], until 2018 the production capacity 405 liters/ second and operates 330

${ }^{1}$ Danang Budi Setyawan and Nieke Karnaningroem are with Department of Environmental Engineering, Institut Teknologi Sepuluh Nopember, Surabaya, Indonesia. Email: danangbudis83@gmail.com; n.karnanngroem@gmail.com. liter/second, to serve 34,319 SR units, with domestic customers (households) as many as 32,271 units, service coverage $41 \%$ while water leakage rates $25 \%$. For continuity still not fulfilled with the frequent water does not flow in the peak hours of use.

Increasing the service of drinking water supply, PDAM must have an effort to meet the criteria in terms of quantity, quality and continuity. One effort to improve water supply services is to optimize the drinking water distribution system by evaluating distribution network systems, water loss rates and water stability indexes in the distribution system.

According to PP No: 122 of 2015 concerning drinking water supply system paragraph 1 which says SPAM is held to provide drinking water services to the public to fulfill the people's right to drinking water[2]. In addition, to support universal access (100-0-100) and the Sustainable Development Goals (SDGs) until 2030, namely clean water and proper sanitation. So to get access to $100 \%$ drinking water, research is carried out to help contribute ideas in order to improve drinking water services in Banyuwangi Regency with the research title: "Existing Evaluation and efforts to improve the distribution network of Banyuwangi District PDAM (Banyuwangi City Study Area).

\section{RESEARCH METHODS}

\section{A. Study location}

The research location is the Banyuwangi City area which is part of the PDAM service in Banyuwangi Regency covering five sub-districts consisting of Banyuwangi District, Kabat District, Glagah District, Giri District, Kalipuro District.

\section{B. Method}

In the preparation of this study is to evaluate drinking water services and infrastructure of drinking water management systems (SPAM) that have been built to determine strategies in an effort to improve drinking water services in Banyuwangi Regency PDAM in the service area of Banyuwangi City through the improvement of the existing distribution network. The achievement indicators can be identified by analyzing the service data and the conditions of the existing SPAM infrastructure from the Banyuwangi Regency PDAM for the Banyuwangi City 
area, the research methods implemented can be described as follows:

\section{1) Data collection.}

Data collected are primary data and secondary data obtained from the relevant agencies in the form of documentation, statistical maps and so on.

- Secondary data.

That is to see all installations / networks in PDAM Banyuwangi Regency and other equipment that have an effect on the distribution system with the aim of knowing the existing network conditions of the PDAM Banyuwangi Regency

- Primary data

Primary data is data obtained by conducting interviews directly with respondents or by filling out questionnaires and direct goals towards the object of research. Primary data includes:

1) Field survey

That is to see all installations / networks in PDAM Banyuwangi Regency and other equipment that have an effect on the distribution system with the aim of knowing the existing network conditions of the PDAM Banyuwangi Regency.

2) Conduct questionnaires for customers PDAM and non customers PDAM

In sampling from members of the population at random, the number of 398 samples circulated is calculated using a formula (Slovin, 1960) quoted in sugiyono, 2018[3]. Calculation of the comparison of PDAM customers is $44 \%$ and non-customers is $57 \%$.

TABLE 1.

PERCENTAGE OF CUSTOMER PDAM AND NON PDAM

\begin{tabular}{crc}
\hline \hline Keterangan & Jumlah & Prosentase \\
\hline sambungan PDAM & 34.319 & $43,6 \% \sim 44 \%$ \\
KK non pelanggan & $44.360,5$ & $56,4 \% \sim 57 \%$ \\
\hline \hline
\end{tabular}

\begin{tabular}{|c|c|c|c|c|c|c|}
\hline No & $\begin{array}{c}\text { Nama } \\
\text { Kecamatan }\end{array}$ & $\begin{array}{c}\text { Jumlah } \\
\text { Penduduk } \\
\text { (Jiwa) }\end{array}$ & $\begin{array}{c}\text { Persentasi } \\
(\%)\end{array}$ & $\begin{array}{c}\text { Jumlah } \\
\text { Sampel } \\
\text { (KK) }\end{array}$ & $\begin{array}{c}\text { Pelanggan } \\
\text { (PDAM) }\end{array}$ & $\begin{array}{c}\text { Non } \\
\text { Pelanggan }\end{array}$ \\
\hline 1 & Banyuwangi & 110042 & $35 \%$ & 139 & 61 & 78 \\
\hline & Giri & 29692 & $9 \%$ & 38 & 16 & 21 \\
\hline & Glagah & 37455 & $12 \%$ & 47 & 21 & 27 \\
\hline & Kalipuro & 77426 & $25 \%$ & 98 & 43 & 55 \\
\hline & Kabat & 60103 & $19 \%$ & 76 & 33 & 43 \\
\hline & Jumlah & 314718 & $100 \%$ & 398 & 174 & 224 \\
\hline
\end{tabular}

2) Evaluation and discussion

Data obtained at the data collection stage will then be processed to obtain results in accordance with the research objectives. Data analysis or evaluation is based on the technical aspects that include:

- Water balance related to NRW Understanding the amount of water entering the system, official water consumption and water loss and calculating the components of water loss in the water balance are expected to help the PDAM make priority handling by making a water balance (WB) using WB-Easy Calc 2018 software[4].

- Distribution Network, analyzing distribution systems related to production and distribution capacity to meet the needs of drinking water by analyzing water pressure, piping conditions from existing data using the epanet 2.0 application[5].

\section{RESULTS AND DISCUSSION}

\section{A. Real Need Survey}

The Real Demand Survey was conducted to determine the existing conditions of the existing water distribution system, and to determine the community's needs for clean water consumption in the city of Banyuwangi,and the following result are obtained

\section{1) PDAM Customer Respondents}

Based on the survey results, it can be evaluated that the majority of PDAM customer respondents in 1 (one) house are 4.45 people, which are then rounded up to 4 (four) people, with the main job being civil servants / TNI / Polri / Private Employees and entrepreneurs who have a monthly income of more than Rp. 2,132,779.35 (Banyuwangi Regency minimum wage according to East Java Governor Decree No: 188/665 / KPTS / 013/2018 concerning Regency / City minimum wages in East Java in 2019). Water use is used for all household activities with an average consumption per month of 18,660 liters (18.66 cubic meters).

The level of customer satisfaction in terms of the quality of water obtained all states in general clear, but in certain conditions or situations the level of community and water pressure decreases.

\section{2) Non Customer PDAM}

All non-PDAM customers use groundwater sources from both bore wells and dug wells and to fulfill daily life needs. and for responses to the PDAM if there is a government program to expand PDAM network installations, with a majority of $71 \%$ interested.

\section{B. Evaluation of Technical Aspects of Drinking Water in} Urban Areas

\section{1) Calculation of Water Balance (Water Balance)}

Water balance is very important in the program to reduce water loss. Because the water balance can be used as a framework for assessing water loss conditions, it can also show the magnitude of each component of the water balance, including the sources and costs of water loss and future planning.

Calculation of water balance in this study using the WBEasyCalc version 5.16 program. Based on data from water balance analysis using the WB-EasyCalc version 5.16 program. the current condition of the percentage of water loss is $25 \%$ with a composition of physical water loss of $22 \%$, and non-physical water loss of $3 \%$ 
IPTEK Journal of Proceedings Series No. (5) (2019), ISSN (2354-6026)

The $1^{\text {st }}$ International Conference on Business and Management of Technology (IConBMT)

August 3rd 2019, Institut Teknologi Sepuluh Nopember, Surabaya, Indonesia

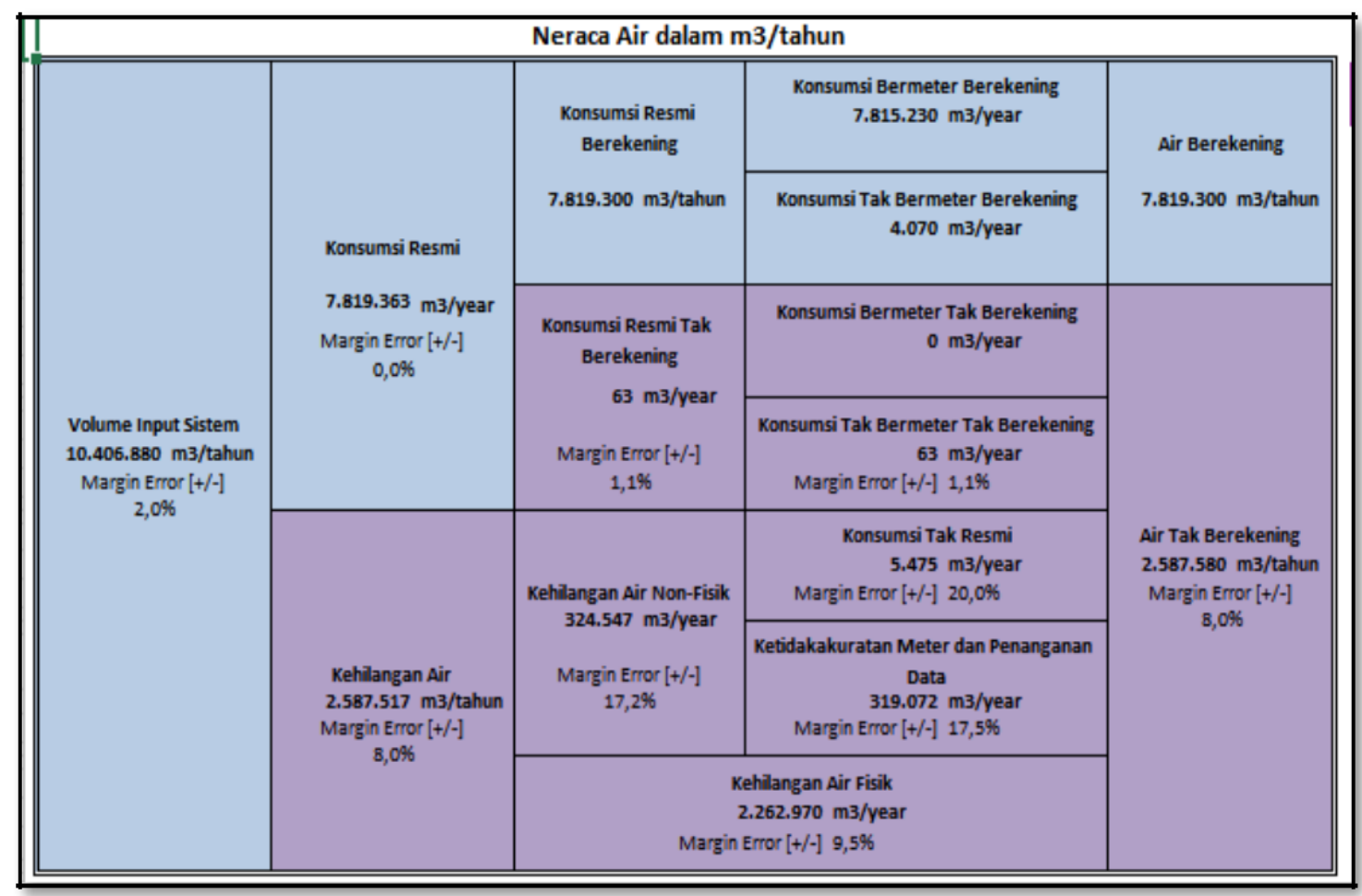

Figure 1. Water balance analysis with WB-EasyCalc version 5.16

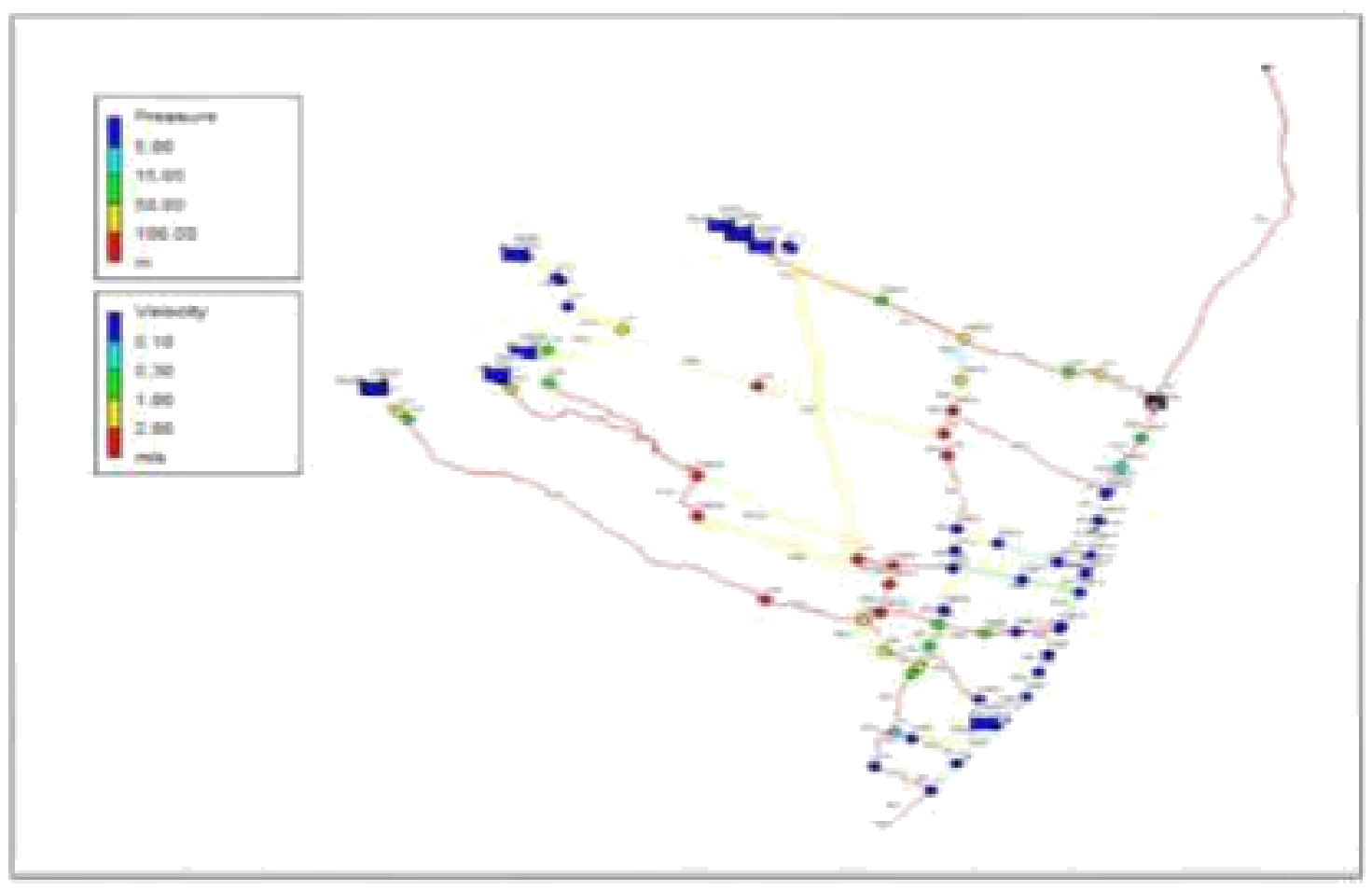

Figure 2. Simulation results of the main distribution network (Existing) 


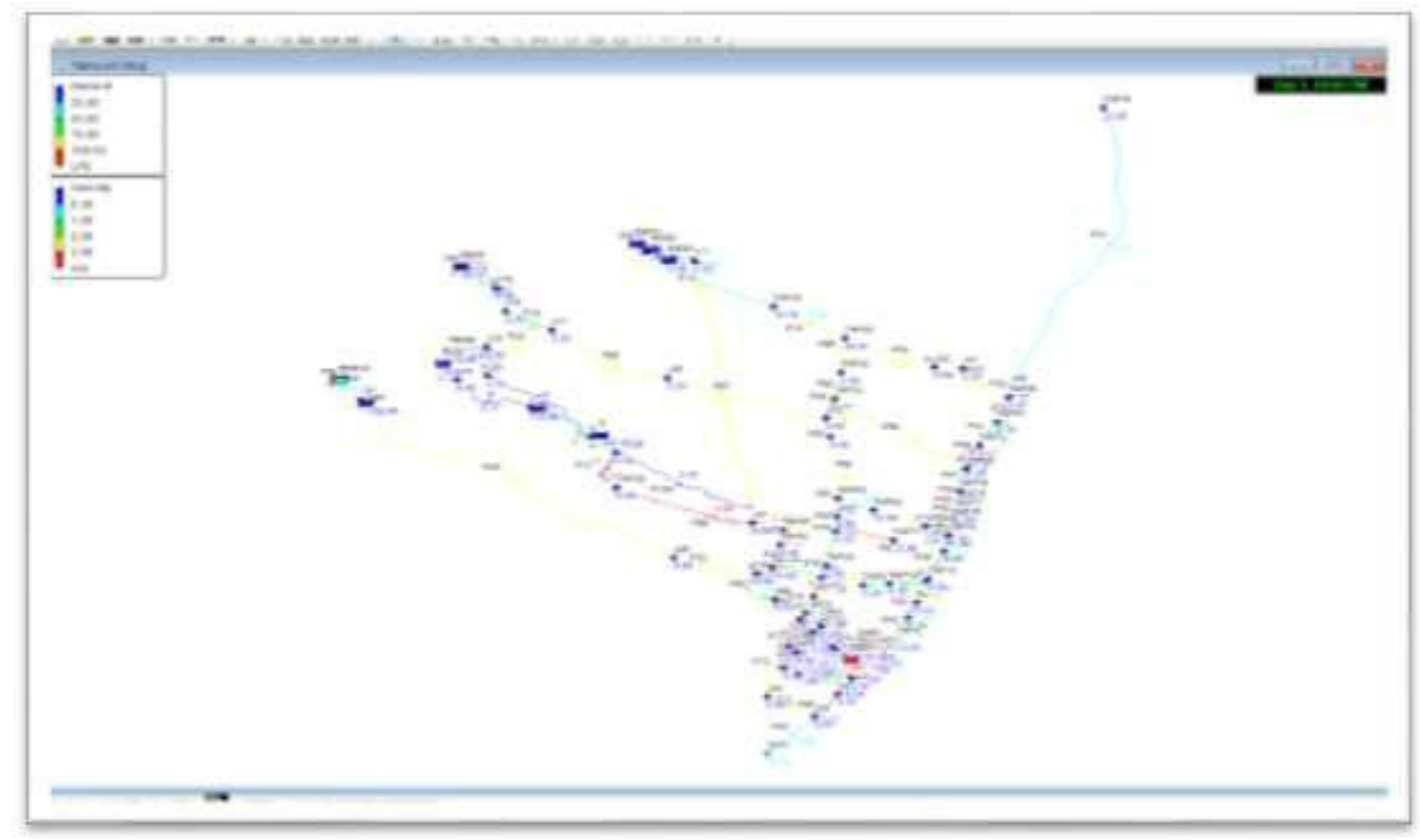

Figure 3. Repair of the main distribution network.

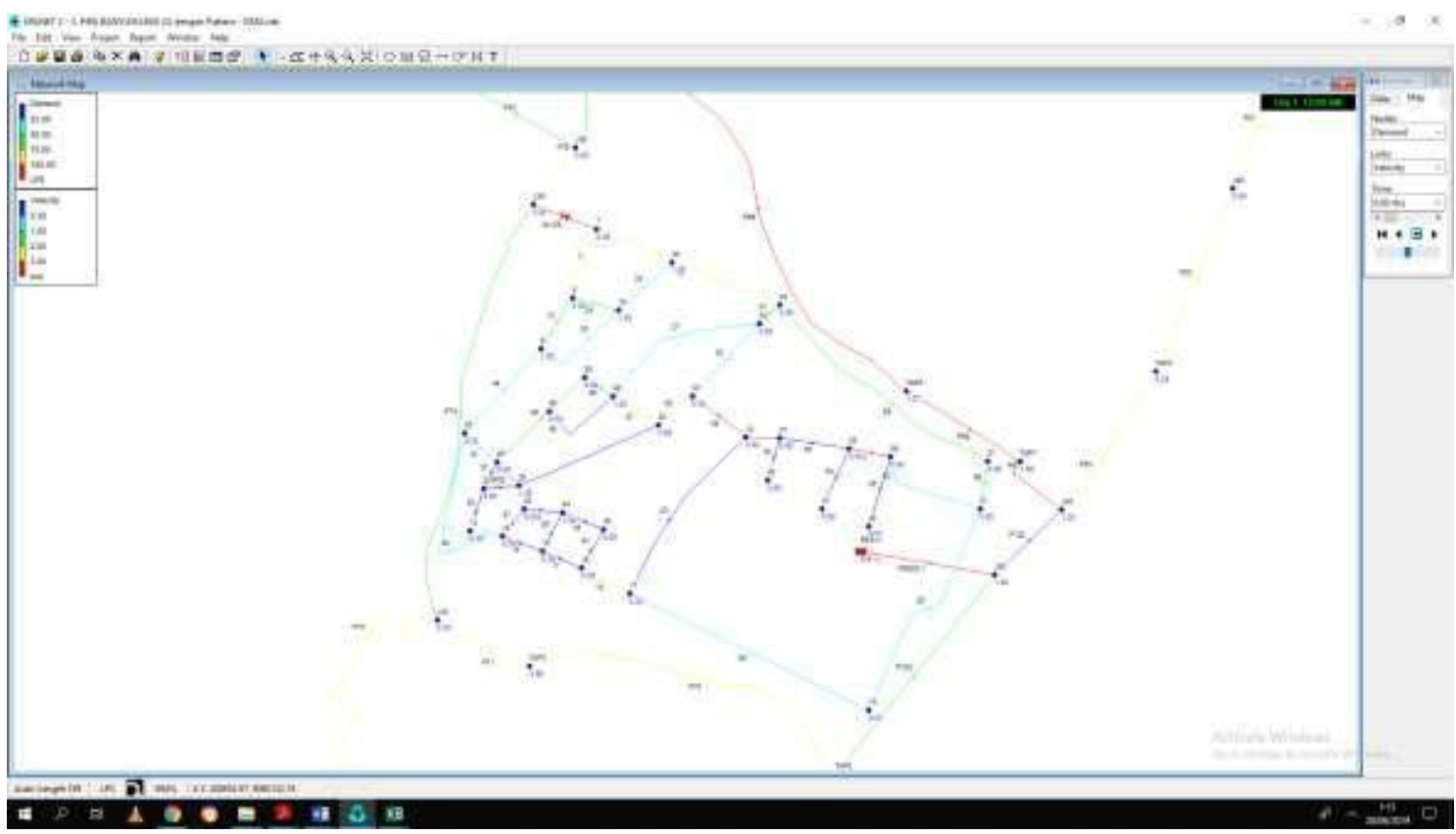

Figure 4. Simulation with the establishment of the Meter Area District (DMA)

\section{2) Evaluate with Epanet}

Evaluation with epanet as illustrated below, with the results of the value of the speed of the flow of the existing network, some of which meet the criteria of minimum 0.3 to a maximum of $3 \mathrm{~m} / \mathrm{sec}[6]$, and some do not meet or exceed the maximum limit due to elevation which is too steep or because of the small diameter of the pipe therefore after analyzing the existing main distribution pipeline network through simulation using epanet 2.0 software, improvement efforts are needed and are guided by the
Minister of Public Works Regulation No: 27 of 2016 concerning the provision of drinking water systems.

Epanet simulation results, pressure at minimum water consumption hours (01:00) at all service areas still meet the standards of more than $10 \mathrm{~m}$. The peak water consumption hours (17:00) still meet the standards. This is due to the addition of BPT in the upper area to reduce or isolate the pressure so that the pipe does not leak. In addition, the replacement of pipes with different diameters in order to regulate the speed. 
Running results in the Sobo area which are formed by DMA can be known, namely for the value of pressure (velocity) and the velocity of the pipe (velocity), velocity (velocity), based on the Epanet simulation results, there are many distribution pipelines in this service area Flow[7].

In addition, with the formation of DMA can facilitate monitoring of water usage by customers, simplify the search for distribution pipeline leakage, facilitate scheduling of production meter replacement, master meter and customer meter, facilitate illegal connection tracking (illegal connection), distribution network system optimization (pressure management). DMA can be isolated permanently and there is no intervention during operation which is equipped electronic watermeter and PRV as shown in this picture.

\section{CONCLUSIONS}

Based on the analysis that has been done can be concluded, among others:

- With water balance, water loss can be $25 \%$ with a composition of physical water loss of $22 \%$, and nonphysical water loss of $3 \%$. So that the volume of water in the pipeline distribution network decreases and does not reach the PDAM customers.

- With epanet 2.0 simulation on the existing distribution network, repairs are needed to meet or comply with the
Minister of Public Works Regulation No: 27 of 2016 concerning the operation of drinking water supply systems.

So it can be concluded that technical steps are needed to overcome these problems, among others, by establishing a service zone (DMA) and replacing old pipes but still operating, one of which is the replacement of artificial pipes in the Dutch era which are still operating.

\section{REFERENCES}

[1] BAPPEDA Banyuwangi, RISPAM Kota Banyuwangi. Banyuwangi, 2013.

[2] Pergub Provinsi DKI Jakarta No. 122 Tahun 2005 tentang Pengolahan Air Limbah Domestik di Provinsi Daerah Khusus Ibukota Jakarta.

[3] S. Sugiyono, Metode Penelitian Kombinasi. Bandung: Alfabeta, 2018.

[4] United States Agency for International Development (USAID) and World Bank Institute, The Manager of Non-Revenue Water Handbook for Africa: A Guide to Understanding Water Loses. United States Agency for International Development (USAID), 2010.

[5] L. A. Rossman, EPANET 2.0: Users Manual. Cincinnati, OH: U.S. ENVIRONMENTAL PROTECTION AGENCY, 2000.

[6] Badan Standarisasi Nasional (BSN), SNI 7507 : 2011 Spesifikasi Bangunan Pelengkap Unit Instalasi Pengolahan Air. Jakarta: Badan Standarisasi Nasional (BSN), 2011.

[7] S. Alvisi and M. Franchini, "A procedure for the design of district metered areas in water distribution systems," Procedia Eng., vol. 70, pp. 41-50, Jan. 2014. 